\title{
MODEL PEMBELAJARAN ARIAS UNTUK MENINGKATKAN AKTIVITAS DAN HASIL BELAJAR SISWA MATA PELAJARAN MATEMATIKA DI KELAS VII SMP
}

\author{
Khidayatul Aulia ${ }^{1}$, Rusdi ${ }^{2}$, Dewi Herawaty ${ }^{3}$ \\ 1,2,3 Program Studi Pendidikan Matematika JPMIPA FKIP Universitas Bengkulu \\ email: ${ }^{1}$ khidayatulaulia@gmail.com, ${ }^{2}$ rusdipendmat12@gmail.com, ${ }^{3}$ dewiherawaty@ gmail.com
}

\begin{abstract}
Abstrak
Tujuan penelitian ini adalah untuk mendeskripsikan peningkatkan aktivitas dan hasil belajar siswa dalam pembelajaran matematika. Jenis penelitian ini adalah PTK kolaboratif yang dilaksanakan dalam tiga siklus dengan alur penelitian yaitu: rencana tindakan, pelaksanaan tindakan, observasi dan refleksi. Subyek penelitian yang dikenai tindakan adalah siswa kelas VIIB SMP Negeri 01 Talang Empat yang berjumlah 25 siswa. Metode pengumpulan data melalui metode observasi dan tes hasil belajar. Keabsahan data dilakukan dengan observasi secara terus menerus dan tes hasil belajar setiap akhir siklus. Hasil penelitian ini menunjukkan adanya peningkatan aktivitas belajar dan hasil belajar siswa pada pembelajaran matematika melalui model pembelajaran ARIAS. Sehingga dapat disimpulkan bahwa penerapan model pebelajaran ARIAS dalam pembelajaran matematika dapat meningkatkan aktivitas belajar dan hasil belajar siswa.
\end{abstract}

Kata kunci: model pembelajaran ARIAS, aktivitas siswa, hasil belajar siswa

\begin{abstract}
The purpose of this study was to describe the enhancement of student learning activities and student learning outcomes in learning mathematics. This type of research is collaborative PTK conducted in three cycles with the research flow that is: action plan, action implementation, observation and reflection. Subjects of this research were students of grade VIIB SMP Negeri 01 Talang Empat which amounted to 25 students. Methods of data collection was through observation and test of learning outcomes. The validity of the data is done by continuous observation and test of learning outcomes at the end of each cycle. The results of this study indicate enhancement in learning activities and student learning outcomes in learning mathematics through ARIAS learning model. The conclusion of this research is that the application of ARIAS learning model in mathematics learning can increase learning activity and student learning outcomes.
\end{abstract}

Keywords: ARIAS learning model, student activity, student learning outcomes

\section{PENDAHULUAN}

Salah satu tujuan pembelajaran di sekolah adalah untuk meningkatkan hasil belajar atau prestasi belajar siswa. Jihad dan Haris (2012: 11) mengemukakan bahwa pembelajaran merupakan suatu proses yang terdiri dari kombinasi dua aspek, yaitu belajar tertuju kepada apa yang harus dilakukan oleh siswa, mengajar berorientasi pada apa yang harus dilakukan oleh guru sebagai pemberi pelajaran.

Faktor utama yang mempengaruhi prestasi belajar siswa adalah penggunaan model atau metode pembelajaran yang tepat. Oleh karena itu untuk meningkatkan hasil belajar siswa diperlukan inovasi dalam kegiatan pembelajaran. Berkenaan dengan hal itu, dapat digunakan suatu model pembelajaran yang disebut dengan model pembelajaran ARIAS (Assurance, Relevance, Interest, Assessment, dan Satisfaction). Model pembelajaran ARIAS ini dapat digunakan oleh para guru sebagai dasar melaksanakan kegiatan pembelajaran dengan baik, dan sebagai suatu alternatif dalam usaha meningkatkan motivasi berprestasi dan hasil belajar siswa. Dengan menerapkan pembelajaran ARIAS diharapkan kegiatan pembelajaran lebih efektif, sederhana, sistematik, dan bermakna sehingga dapat meningkatkan hasil belajar siswa. 
Pembelajaran matematika adalah proses yang sengaja dirancang dengan tujuan untuk menciptakan suasana lingkungan memungkinkan seseorang melaksanakan kegiatan belajar matematika, dan proses tersebut berpusat pada guru mengajar matematika dengan melibatkan partisipasi aktif peserta dididk didalamnya (Dimyati dan Mudjiono,2013:65). Pada sisi lain, matematika merupakan bidang studi yang dipelajari siswa dari SD hingga jenjang perguruan tinggi dan matematika juga digunakan sebagai bekal untuk melanjutkan pendidikan ke jenjang yang lebih tinggi. Matematika merupakan salah satu materi pelajaran yang penting dan sangat diperlukan dalam perkembangan ilmu pengetahuan dan teknologi, namun dipihak lain matematika dianggap sebagai mata pelajaran yang menakutkan bagi siswa, sehingga hasil pembelajaran yang diperoleh siswa belum sebagaimana yang diharapkan.

Hasil pengamatan di kelas VII B SMP Negeri 01 Talang Empat dalam pembelajaran matematika guru sudah menguasai materi dengan baik akan tetapi dalam pelaksanaan kegiatan pembelajaran, diawal proses belajar mengajar guru belum maksimal menanamkan rasa percaya diri pada siswa dan tidak menghubungkan materi dengan kehidupan siswa sehari-hari sehingga membuat siswa tidak termotivasi untuk belajar dan membuat siswa merasa bosan kemudian menganggap bahwa pelajaran matematika itu susah dan membuat pelajaran matematika ditakuti siswa disekolah. Kegiatan pembelajaran di atas cenderung membuat siswa belum maksimal dalam mengembangkan kemampuan karena guru kurang memperhatikan rasa percaya diri dan minat siswa yang membuat siswa kurang bersemangat untuk mengikuti proses belajar mengajar yang sedang berlangsung. Berkenaan dengan hal itu maka dengan memperhatikan berbagai konsep dan teori belajar di terapkanlah suatu model pembelajaran yang disebut dengan model pembelajaran ARIAS (Assurance, Relevance, Interest, Assessment, Satisfaction).

Pengertian dari komponen-komponen ARIAS yaitu Assurance ataupun kepercayaan diri merupakan komponen model pembelajaran
ARIAS yang pertama. "Dalam masalah ini, percaya diri yang dimaksudkan adalah raya percaya diri pada siswa."(Rahman dan Amri,2014:56). "Relevansi dengan mata pelajaran, karena bagaimanapun kegiatan proyek ini harus dimulai dari masalah yang ada kaitannya langsung dengan mata pelajaran tertentu yang sedang dipelajari" (Arikunto,2013:252). Sardiman (2014:195) mendefinisikan "Yang dimaksud dengan interest dalam hal ini ialah usaha guru untuk menarik atau membawa perhatian siswa pada materi pelajaran yang baru". Gunawan (2014:92) menyatakan "Evaluasi merupakan salah satu rangkaian kegiatan dalam meningkatkan kualitas, kinerja, atau produktifitas suatu lembaga dalam melaksanakan programnya". Rusman (2011:113) mendefinisikan "Penguatan adalah pemberian respons dalam proses interaksi belajar mengajar baik berupa pujian maupun sanksi". Model pembelajaran ARIAS merupakan model pembelajaran yang dapat mengarah untuk menanamkan rasa percaya diri (Assurance) dan bangga kepada siswa, membangkitkan minat atau perhatian (interest), serta memberi kesempatan kepada mereka untuk mengadakan evaluasi diri(assessment). Model pembelajaran ini adalah model pembelajaran yang dirancang dan dapat digunakan oleh guru untuk mempengaruhi motivasi berprestasi dan prestasi belajar siswa. Dalam model ARIAS dituntut kreativitas guru dalam memilih cara mengajar untuk dapat membantu siswa lebih tertarik (interest) terhadap pembelajaran.

\section{METODE}

Penelitian ini merupakan Penelitian Tindakan Kelas (PTK), yaitu penelitian bersifat kolaboratif yang didasarkan pada permasalahan yang muncul dalam mata pelajaran matematika kelas VII B SMPN 01 Talang Empat. Daryanto (2014:1) menyatakan penelitian tindakan kelas (PTK) pada dasarnya merupakan kegiatan nyata yang dilakukan guru dalam rangka memperbaiki mutu pembelajaran dikelas, serta PTK dimulai dari tahap perencanaan setelah ditemukannya masalah dalam pembelajaran, dilanjutkan dengan pelaksanaan tindakan, 
pengamatan, dan refleksi.Dalam pelaksanaan PTK perlu di-lakukan siklus tindakan yang mengacu pada penguasaan yang ditargetkan yaitu menggunakan model penelitian tindakan Kemmis dan Tanggart (1990) yang berbentuk spiral, dengan tahapan penelitian tindakan pada satu siklus meliputi perencanaan (planning), tindakan (action), pengamatan (observation), dan refleksi (reflection). Metode pengumpulan data menggunakan test, observas. Analisis data menggunakan deskriptif kualitatif.

\section{Rencana Tindakan}

Kegiatan pada tahap ini peneliti menemukan dan merumuskan masalah secara jelas dan spesifik, menemukan hipotesis yang diyakini dapat digunakan untuk memecahkan masalah tersebut. Penelitian perlu beberapa hal yang berkaitan dengan proses pengambilan data dan proses pembelajaran yaitu antara lain: Rencana Pelaksanaan Pem-belajaran, Bahan ajar (Hand Out), dan Lembar observasi dan mendesain alat evaluasi. Yang nantinya bertujuan supaya dalam pengambilan data maupun dalam proses pembelajaran berjalan sesuai dengan yang diharapkan.

\section{Rencana Pelaksanaan}

Tahap pelaksanaan ini adalah suatu tahap yang dilakukan setelah dibuatnya perencanaan atau tahap yang didalamnya melaksanakan perencanaan yang telah dibuat. Dalam tahap ini peneliti menggunakan strategi pembelajaran model perolehan konsep modifikasi ARIAS, dengan langkah langkah sebagai berikut :

1) Menjelaskan tujuan pembelajaran Membangkitkan rasa percaya diri siswa dengan memberikan motivasi bahwa pelajaran atau materi yang akan dipelajari adalah materi yang mudah dan pasti bisa dipa-hami oleh setiap siswa.

2) Mengemukakan manfaat materi yang akan dipelajari terhadap siswa, dengan menggunakan bahasa yang jelas.

3) Peneliti menyampaikan materi

4) Bentuk kelompok terdiri 5 orang secara heterogen.

5) Masing-masing kelompok mengidentifikasi tugasnya.

6) Setiap kelompok diberikan kesem- patan untuk mempresentasikan hasil kerjanya, kelompok lainnya menyimak dan diberi kesempatan menge-valuasi kelompok yang presentasi.

7) Setiap aktivitas di evaluasi baik individu maupun kelompok.

8) Peneliti memberikan penghargaan terhadap kelompok yang terbaik.

\section{Observasi/ Pengamatan}

Pengamatan (observasi) adalah metode pengumpulan data dimana peneliti mencatat informasi sebagaimana yang mereka saksikan selama penelitian, disini yang bertindak sebagai observer adalah pengamat 2 / teman peneliti sesuai lembar observasi yang telah disiapkan.

Setiap butir observasi pada lembar observasi diberi kriteria penilaian dengan notasi seperti tabel berikut:

Tabel 1. Kriteria penilaian untuk lembar observasi aktivitas siswa

\begin{tabular}{|c|c|c|l|}
\hline No & $\begin{array}{c}\text { Kategori } \\
\text { Penilaian }\end{array}$ & Notasi & \multicolumn{1}{|c|}{ Skor } \\
\hline 1 & Kurang & $\mathrm{K}$ & $\begin{array}{l}1,00 \leq \mathrm{x} \leq \\
1,50\end{array}$ \\
\hline 2 & Cukup & $\mathrm{C}$ & $\begin{array}{l}1,51 \leq \mathrm{x} \leq \\
2,49\end{array}$ \\
\hline 3 & Baik & $\mathrm{B}$ & $\begin{array}{l}2,50 \leq \mathrm{x} \leq \\
3,00\end{array}$ \\
\hline
\end{tabular}

Lembar observasi siswa diolah menggunakan persamaan berikut:

$$
\begin{aligned}
& \text { Rata-rata }=\frac{\text { Jumlah skor }}{\text { Banyak Pengamat }} \\
& \text { Kisaran nilai untuk tiap kriteria } \\
& =\frac{\text { SkorTertinggi }- \text { SkorTerendah }+1}{\text { JumlahKriteria }} \\
& \text { (Modifikasi Sudijono, 2003: 49-50) }
\end{aligned}
$$

Skor Tertinggi = jumlah butir observasi $x$ skor tertinggi tiap butir observasi

Skor Terendah $=$ jumlah butir observasi $x$ skor terendah tiap butir observasi

Menghitung hasil penelitian oleh kedua observer pada lembar observasi aktivitas siswa setiap siklus dengan rumus dimodivikasi dari Daryanto (2014:192).

Keterangan

$$
\bar{A}=\frac{\bar{P}_{1}+\bar{P}_{2}}{2}
$$

$\bar{A} \quad=$ Nilai rata-rata skor aktivitas siswa hasil observasi oleh teman sejawat 
$\bar{P}_{1}=$ Nilai rata-rata skor aktivitas siswa hasil observasi oleh pengamat 1

$\bar{P}_{2} \quad=$ Nilai rata-rata skor aktivitas siswa hasil observasi oleh pengamat 2

Kisaran skor penilaian untuk lembar observasi aktivitas siswa adalah :

Tabel 2. Kriteria Skor Pengamatan untuk Lembar Observasi Aktivitas Siswa

\begin{tabular}{|c|c|}
\hline $\begin{array}{c}\text { Kategori } \\
\text { Penilaian }\end{array}$ & Kisaran Skor \\
\hline Kurang Aktif & $13,00 \leq \mathrm{x} \leq 21,67$ \\
\hline Cukup Aktif & $21,68 \leq \mathrm{x} \leq 30,34$ \\
\hline Aktif & $30,35 \leq \mathrm{x} \leq 39,00$ \\
\hline
\end{tabular}

(Modifikasi Sudjana, 2009:77)

\section{Refleksi}

Refleksi adalah merenung kembali pengalaman (dalam hal ini belajar) yang sudah dijalani, sehingga dapat melihat apa yang sudah terjadi. Dalam hal ini tahap refleksi adalah tahap penyimpulan dari dampak perencanaan yang telah dilakukan. Hasil dari kegiatan refleksi ini akan dijadikan dasar untuk merencanakan

tindakan yaitu melaksanakan siklus II, siklus ini digunakan untuk memperbaiki kekurangan-kekurangan yang terjadi pada saat pembelajaran yang berlangsung pada siklus I. Siklus ke II dilanjutkan bila dari hasil refleksi belum mencapai target.

\section{Analisis Data}

Analisis data dalam penelitian Tindakan kelas ini adalah menggunakan aspek kognitif dimana bisa diperoleh dari nilai hasil tes tertulis. Walaupun aspek kognitif sangat menentukan suatu pembelajaran, namun aspek afektif dan aspek psikomotorik juga menentukan kualitas suatu proses pembelajaran. Hasil penilaian / data dianalisis dengan mempergunakan sistem skor dengan rumus :

Nilai akhir rata-rata hasil belajar setiap siswa diperoleh dari menjumlahkan seluruh skor dan dibagi dengan banyak objek. Adapun rata-rata nilai akhir siswa dihitung dengan menggunakan rumus:

$$
\bar{X}=\frac{\sum X}{N}
$$

(Modifikasi Aqib,dkk 2014:204)

$\bar{X}=$ Rata-rata nilai siswa

$\sum X=$ Jumlah seluruh skor

$N=$ Banyak objek

Persentase Ketuntasan Belajar Klasikal

$$
P=\frac{\text { Ssiswayangtuntasbelajar }}{\text { Lsiswa }} \times 100 \%
$$

(Aqib, dkk, 2009: 41)

Keterangan:

P: Persentase Ketuntasan Belajar Klasikal

Siswa dikatakan tuntas belajar jika memperoleh nilai 70

Penelitian dikatakan berhasil jika memenuhi indikator keberhasilan tindakan berikut :

1) Kegiatan pembelajaran Matematika menggunakan model pembelajaran ARIAS di SMPN 01 Talang Empat kelas VII B dapat mencapai kriteria baik untuk hasil aktivitas siswa dan guru yaitu berada pada interval 30-39 maka siswa dikatakan aktif, maka guru $\bar{X}=$ Rata-rata nilai siswa

2) Hasil belajar siswa meningkat jika:

a. Kegiatan pembelajaran Matematika menggunakan model pembelajaran ARIAS di kelas VII B dikatakan dapat meningkatkan hasil belajar siswa jika minimal rata-rata klasikal siswa telah mencapai $\geq \mathrm{KKM}$ mata pelajaran matematika yaitu 70 .

b. Minimal $80 \%$ siswa memperoleh nilai $\geq 70$.

\section{HASIL DAN PEMBAHASAN}

Penelitian ini dilakukan dalam upaya meningkatkan aktivitas dan hasil belajar siswa dengan menggunakan model pembelajaran ARIAS pada siswa. Data yang diperoleh dalam penelitian ini adalah didasarkan dari observasi secara langsung dan tes hasil belajar siswa yang dilaksanakan sebanyak 3 siklus. Selain data observasi juga diperoleh data dari hasil tes siswa. Berikut ini adalah hasil analisis penting dari penelitian yang dilakukan selama berlangsungnya proses pembelajaran dengan mengunakan model pembelajaran ARIAS, seperti terlihat pada tabel 4.12 berikut ini. 
Tabel 3. Rekapan Hasil Observasi Aktivitas Siswa Setiap Siklus

\begin{tabular}{|c|c|c|c|c|}
\hline $\begin{array}{c}\text { Sik } \\
\text { lus }\end{array}$ & $\begin{array}{c}\text { Skor } \\
\text { rata- } \\
\text { rata } \\
\text { penga } \\
\text { mat 1 }\end{array}$ & $\begin{array}{c}\text { Skor } \\
\text { rata- } \\
\text { rata } \\
\text { penga } \\
\text { mat 2 }\end{array}$ & $\begin{array}{c}\text { Skor } \\
\text { rata- } \\
\text { rata } \\
\text { kesel } \\
\text { uruha } \\
\text { n }\end{array}$ & $\begin{array}{c}\text { Kriteri } \\
\mathbf{a}\end{array}$ \\
\hline I & 22,33 & 21,33 & 21,83 & $\begin{array}{c}\text { Cukup } \\
\text { aktif }\end{array}$ \\
\hline II & 28,00 & 28,00 & 28,00 & $\begin{array}{c}\text { Cukup } \\
\text { aktif }\end{array}$ \\
\hline III & 34,00 & 33,33 & 33,67 & Aktif \\
\hline
\end{tabular}

Tabel di atas menunjukkan rekapan hasil observasi aktivitas siswa setiap siklus terlihat bahwa terjadi peningkatan disetiap siklusnya. Pada siklus I dengan rata-rata skor 21.83 masih tergolong cukup aktif, aktivitas siswa mulai meningkat pada siklus II menjadi aktif dengan rata-rata skor 28,00. Pada siklus III aktivitas siswa sudah mencapai indikator keberhasilan yaitu sebesar 33,67.

Peningkatan yang terjadi setiap siklusnya, sesuai dengan model pembelajaran ARIAS yaitu untuk meningkatkan kepercayaan diri siswa, menghubungkan materi dengan kehidupan sehari-hari, dan siswa termotivasi untuk belajar matematika, serta menyelesaikan soal-soal yang diberikan oleh guru.

Adapun rekapan hasil belajar siswa ditunjukkan pada tabel 4.13 seperti dibawah ini.

Tabel 4. Rekapan Hasil Belajar Siswa Setiap Siklus

\begin{tabular}{|c|c|c|c|}
\hline Siklus & $\begin{array}{c}\text { Nilai } \\
\text { Rata- } \\
\text { rata }\end{array}$ & $\begin{array}{c}\text { Jumlah } \\
\text { siswa } \\
\text { yang } \\
\text { mencapai } \\
\text { KKM }\end{array}$ & $\begin{array}{c}\text { Ketuntasan } \\
\text { Klasikal }\end{array}$ \\
\hline I & 24,97 & 0 & $0 \%$ \\
\hline II & 30,60 & 8 & $32 \%$ \\
\hline III & 60,45 & 13 & $52 \%$ \\
\hline
\end{tabular}

Berdasarkan tabel 4 terlihat bahwa setiap siklus mengalami peningkatan pada hasil belajar. Hal ini terlihat pada siklus I hanya 16 orang siswa yang memiliki nilai di atas KKM dengan nilai rata-rata kelas sebesar 68,86 dan ketuntasan klasikal sebesar $64 \%$. Pada siklus II nilai rata-rata siswa meningkat menjadi 70,98 dengan ketuntasan klasikal sebesar $72 \%$. Pada siklus III nilai rata-rata kelas dan ketuntasan klasikal sudah mencapai indikator keberhasilan yaitu masing-masing 72,82 dan $84 \%$.

Peningkatan ketuntasan belajar secara klasikal dapat dilihat pada gambar 1 berikut.

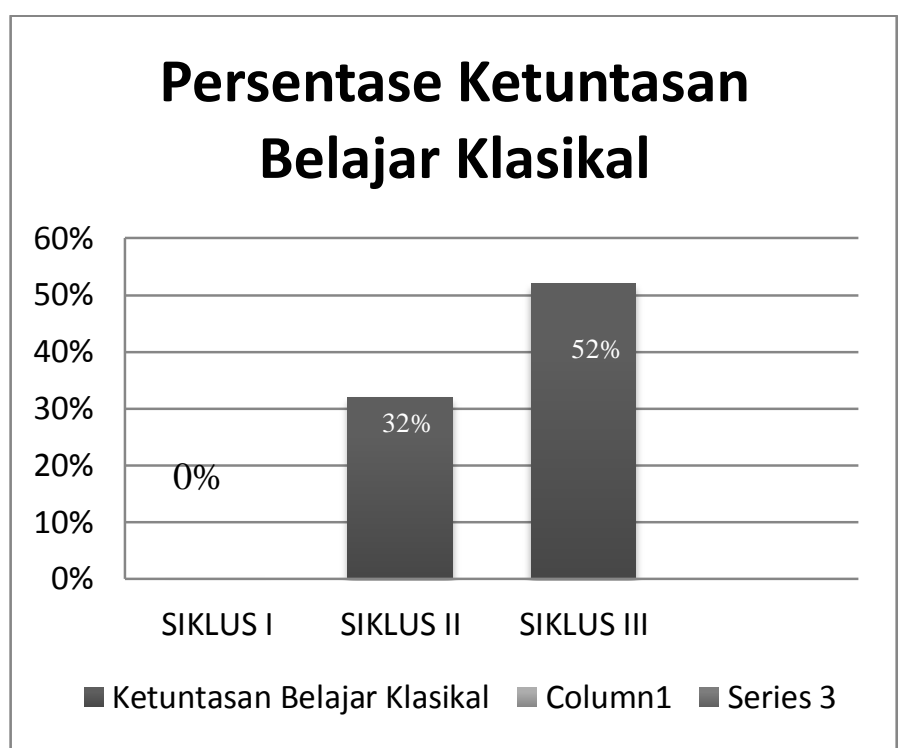

\section{Gambar 1. Grafik Peningkatan Ketuntasan Belajar Klasikal Siswa Tiap Siklus}

Gambar 1 menunjukkan bahwa siklus I ketuntasan belajar klasikal sebesar 0\%. Hal ini berarti tidak terdapat siswa yang memiliki nilai $\geq 70$. Pada siklus II ketuntasan belajar klasikal meningkat menjadi $32 \%$ yang berarti sudah 8 orang siswa yang memiliki nilai $\geq 70$, karena belum memenuhi indikator keberhasilan maka dilanjutkan pada siklus III. Pada siklus III indikator keberhasilan belajar siswa meningkat kembali menjadi $52 \%$, itu berarti 13 orang siswa telah mencapai kriteria ketuntasan minimal yaitu memiliki nilai $\geq 70$. Berdasarkan analisis data hasil tes setiap siklus secara individu perkembangan hasil belajar siswa mengalami perubahan.

Nilai siswa yang meningkat disetiap siklusnya ada 15 orang sedangkan 10 orang lainnya mengalami perubahan nilai yang naik turun dari siklus I hingga siklus III. Berdasarkan nilai analisis tes tiap siklus terdapat 1 orang siswa yang nilainya naik turun sangat drastis yaitu siswa ke 17 . Hal ini terjadi 
karena siswa tersebut tidak serius dalam mengerjakan tes siklus II dan siklus III. Dan terdapat 2 orang siswa yaitu siswa ke 14 dan 19 yang tidak pernah mencapai ketuntasan belajar $\geq 70$ dalam menyelesaikan tes hasil belajar siswa dari siklus I sampai siklus III.

\section{PENUTUP}

\section{Simpulan}

Berdasarkan hasil penelitian yang telah dilaksanakan dikelas VII B SMPN 01 Talang Empat dapat diambil kesimpulan sebagai berikut:

1) Penerapan Model pembelajaran ARIAS dapat meningkatkan aktivitas belajar siswa pada pembelajaran matematika dengan cara:

a. Siswa membentuk kelompok belajar yang diarahkan oleh guru dimana kelompok belajar tersebut bersifat heterogen pada setiap siklus agar menghilangkan rasa bosan terhadap kelompok yang sama dan dapat meningkatkan keefektifan kegiatan diskusi kelompok.

b. Siswa diberikan teguran dan perhatian oleh guru dimana perhatian tersebut diberikan kepada siswa yang kurang serius dan masih bermain-main dan mengganggu teman kelompoknya maupun kelompok lain agar mau mengikuti tahapan pembelajaran dengan baik.

c. Siswa diberikan bimbingan oleh guru yaitu belajar khusus atau perhatian khusus kepada siswa maupun kelompok yang mengalami kesulitan dalam memahami materi maupun menyelesaikann soal LKS.

d. Memberikan motivasi kepada siswa untuk aktif dalam kegiatan pembelajaran dengan memberikan nilai tambahan baik secara kelompok maupun secara individu.

Peningkatan aktivitas siswa dapat dilihat dari rata-rata skor hasil observasi aktivitas siswa siklus I, Siklus II, dan siklus III secara berturut-turut adalah 21,83(kriteria cukup aktif), 28,00 (kriteria cukup aktif) dan 33,67 (kriteria aktif).

2) Tidak terjadinya peningkatan hasil belajar secara signifikan disebabkan oleh:

a. Peneliti belum memiliki pengalaman yang cukup dalam menerapkan pembelajaran matematika yang menerapkan model pembelajaran ARIAS.

b. Siswa belum terbiasa dilibatkan dalam pembelajaran matematika yang menerapkan model pembelajaran ARIAS.

c. Tindakan dalam mengelola pembelajaran belum terlaksana secara maksimal.

Analisis tes siklus I menunjukkan nilai rata-rata siswa 68,86 dengan ketuntasan belajar klasikal $64 \%$, kemudian pada siklus II hasil belajar meningkat dengan nilai rata-rata siswa 70,98 dengan ketuntasan belajar klasikal $72 \%$. Terjadi penurunan pada siklus III dengan nilai rata-rata siswa 60,45 dengan ketuntasan belajar klasikal $52 \%$.

\section{Saran}

Berdasarkan penelitian yang telah dilakukan maka peneliti memberikan beberapa saran, yaitu:

1). Untuk meningkatkan aktivitas belajar siswa, sebaiknya guru memperhatikan :

a. Disarankan bila menggunakan model pembelajaran ARIAS, karena model ini berorientasi pada proses pembelajaran yang bertahap atau selangkah demi selangkah, diharapkan guru memperhatikan sejauh mana materi yang telah dapat diserap oleh siswa.

b. Supaya tingkat kepercayaan terhadap hasil-hasil penelitian lebih tinggi, perlu dilakukan penelitian dengan rentang waktu yang lebih lama.

c. Perlu difikirkan lagi tindakan-tindakan yang memungkinkan terjadinya peningkatan efektivitas penerapan model pembelajaran ARIAS pada pembelajaran matematika.

d. Jika dirasa perlu, lakukan pengujian secara statistik terhadap hasil-hasil antar siklus.

2). Untuk meningkatkan hasil belajar siswa, sebaiknya guru memperhatikan :

a. Tingkat pemahaman siswa terhadap materi prasyarat.

b. Memotivasi dan melatih siswa untuk selalu percaya diri dan teliti.

c. Mengefektifkan alokasi waktu pembelajaran dengan baik. 
DAFTAR PUSTAKA

Arikunto Suharsimi. 2013. Dasar-Dasar Evaluasi Pendidikan. Jakarta: PT.Bumi Aksara.

Aqib, dkk. 2009. Penelitian Tindakan Kelas untuk Guru SD, SLB dan TK. Bandung:CV. Yrama Widya.

Daryanto. 2014. Penelitian Tindakan Kelas dan Penelitian Tindakan Sekolah. Yogyakarta: Penerbit Gava Media.

Dimyati dan Mudjiono. 2013. Belajar dan Pembelajaran. Jakarta: PT. Rineka Cipta.

Gunawan Rudy. 2014. Pengembangan Kompetensi Guru IPS. Jakarta: Alfabeta.

Jihad Asep, Haris Abdul. Evaluasi Pembelajaran. Multi Presindo.
Rahman Muhammat, Amri Sofan. 2014. Model Pembelajaran ARIAS Terintegratif. Jakarta: PT.Prestasi Pustakarya.

Rusman. 2011. Model-Model Pembelajaran Mengembangkan Profesionalisme Guru Cetakan Ke-3. Jakarta: Rajawali Pers.

Sardiman. 2014. Interaksi dann Motivasi Belajar Mengajar.Jakarta: PT. RajaGrafindo Persada.

Sudijono. 2008. Pengantar Evaluasi Pendidikan. Jakarta: PT.Raja Grafindo Persada.

Sudjana. 2005. Metoda Statistika. Bandung: PT. Tarsito. 